\title{
ANALYSIS OF FACTOR AFFECTING INFANT MORTALITY RATE (IMR) IN EAST JAVA USING MULTIPLE LINEAR REGRESSION
}

\author{
Weike Retno Palupi ${ }^{1}$, Lailatul Khusnul Rizki ${ }^{2}$ \\ ${ }^{1}$ Department of Biostatistics and Population, Faculty of Public Health, Universitas Airlangga, 60115 Surabaya, East Java, \\ Indonesia \\ ${ }^{2}$ Midwifery Diploma Study Program, Faculty of Nursing and Midwifery, Universitas Nahdlatul Ulama Surabaya, 60237 \\ Surabaya, East Java, Indonesia \\ Corresponding Author: Weike Retno Palupi \\ E-mail: weikeretno@gmail.com
}

\begin{abstract}
Infant Mortality Rate (IMR) is one of the important indicators in public health. Indonesia still has a relatively high IMR compared to the neighboring countries. Based on the Indonesian Demographic Health Survey (IDHS) in 2012, IMR in East Java reached 25.50 deaths per 1000 births. IMR decline occurred during 2012 to 2015. Achievement depends on the factors that influence it. This study aims to create a model of IMR based on maternal and external factors in East Java. The method used was a non-reactive study using 38 districts/cities as sample units in East Java, which came from Central Bureau of Statistics secondary data in 2015. Statistical analysis used multiple linear regression. The results showed the independent variables together affected the IMR $(\mathrm{p}$-value $=$ $0,000<0.05$ ), but partially influenced by the age of the first married mother ( $\mathrm{p}$-value $=0,000<0.05$ ) and the helper delivery of non-medical personnel ( $p$-value $=0.014<0.05)$. The conclusion of this study is the regression equation model for IMR in East Java in 2015, which is IMR $=1,064+1,319 *$ (age of first marriage) $+0.439 *$ (helper of non-medical births). Suggestions for the Government of East Java Province to implement strategies so that infant mortality cases can be reduced.
\end{abstract}

Keywords: infant mortality rate, mother's age of first married, traditional birth attendance, multiple linear regression

\begin{abstract}
ABSTRAK
Angka Kematian Bayi (AKB) adalah salah satu indikator penting dalam kesehatan masyarakat. Indonesia masih menghadapi $A K B$ yang cukup tinggi dibandingkan dengan negara-negara tetangga. Berdasarkan Survei Kesehatan Demografi Indonesia (SDKI) 2012, AKB di Jawa Timur mencapai 25,50 kematian tiap 1000 kelahiran hidup. Penurunan AKB terjadi pada tahun 2012 hingga 2015. Pencapaian bergantung pada faktor-faktor yang mempengaruhinya. Penelitian ini bertujuan untuk membuat model AKB berdasarkan faktor ibu dan eksternal di Jawa Timur. Metode yang digunakan adalah penelitian non-reaktif dengan menggunakan 38 kabupaten / kota sebagai unit sampel di Jawa Timur, yang berasal dari data sekunder BPS pada tahun 2015. Analisis statistik menggunakan regresi linier berganda. Hasil penelitian menunjukkan variabel independen secara bersama berpengaruh terhadap AKB (nilai $p=0,000<0,05$ ), tetapi secara parsial dipengaruhi oleh usia pertama ibu menikah (nilai $p=0,000<0,05$ ) dan penolong persalinan tenaga nonmedis (nilai $p=0,014<0,05$ ). Kesimpulan dari penelitian ini adalah model persamaan regresi untuk AKB di Jawa Timur pada tahun 2015, yaitu AKB = $1,064+1,319 *$ (usia pernikahan pertama $)+0,439 *($ penolong persalinan nonmedis $)$. Saran bagi Pemerintah Provinsi Jawa Timur untuk menerapkan strategi agar kasus kematian bayi dapat dikurangi.
\end{abstract}

Kata Kunci: angka kematian bayi, umur pertama ibu menikah, penolong persalinan tenaga nonmedis, regresi linier berganda

\section{INTRODUCTION}

Health development in Indonesia aims to increase the level of public health following predetermined targets. According to the government, as an independent nation, the initial steps needed to develop human resources, especially in the health aspect (Sitorus, 2009). Health is the biggest investment in human life, therefore every country will compete to improve health services for all its people.

Infant Mortality Rate (IMR) is one of the important indicators to ensure the degree of 
health in the community. Development in one area can also be considered through the Infant Mortality Rate and Life Expectancy Rate (Aulele, 2012). Definition of Infant Mortality Rate itself is the number of death cases of infants under 1-year-old in that year per 1000 births. While the number of infants deaths is the number of infants who die shortly after the delivery before they reach exactly one year old (Rachmah and Purhadi, 2014). In general, parameters that can be used to ensure the degree of health in the community including life expectancy, infants and toddlers' mortality decreased, infants born with a weight of $\leq 2500$ grams are reduced, and morbidity.

Cases of infant mortality that occur in Indonesia are classified as high compared to other countries. The IMR target in Indonesia in 2015 is 23 deaths per 1,000 births. However, the results of the 2012 IDHS survey said that IMR in Indonesia still reached 32 cases per 1,000 births. The IMR target in East Java decreased from 2012 to 2015, where in 2012 there were 25.5 deaths per 1,000 births, in 2013 there were 25.00 deaths per 1,000 births, in 2014 there were 24.50 deaths per 1,000 births, and in 2015 there were 24.00 deaths per 1000 births (East Java Province Central Bureau of Statistics, 2019).

There are two causes of infant death: direct and indirect causes. The direct cause of infant death is more influenced by the infant's innate factors since birth and is directly related to the health status. For example, low birth weight (LBW), postnatal infections (tetanus neonates), sepsis, hypothermia, asphyxia, and others. While the indirect cause of infant death is influenced by the external environment and maternal activities during pregnancy, such as maternal health services, maternal health during pregnancy, socioeconomic factors, and environmental influences around pregnant women (Syaifuddin, 2011). Infant mortality can also be caused by a lack of family and community awareness of the health of pregnant women, for example, infrequently pregnant women check their pregnancies with health workers, pregnant at high risk, pregnancy distances that are too close, lack of nutrition, environmental sanitation conditions, etc (Sulistyowati, 2009).

Theory from Mosley and Chen (1984) stated that there are five categories related to socio-economic factors, which are maternal factors, environmental pollution factors, nutritional factors, injury or accident factors, and disease control factors in individuals. Some studies that discuss infant mortality have been done by previous researchers, including Winarno (2009) with the conclusion that the percentage of women giving birth assisted by health workers and the average length of time given exclusive breastfeeding can affect infant mortality. While research has been done by Aulele (2012) stated that the average age of first marriage to women, the average expenditure per capita per month, the percentage of the population with poverty, the number of health workers, and the number of health service facilities also affect the infant mortality rate.

Linear regression is a tool or statistical test used to model relationships between variables (dependent and independent). The application of regression analysis is to describe patterns or models and assess the statistical relationship between two or more variables (Wibisono, 2005). If an analysis involves only one independent variable $(\mathrm{X})$, it is called Simple Linear Regression, but if an analysis has two or more independent variables, it is called Multiple Linear Regression. The purpose of this study is to model IMR in East Java in 2015 according to the factors that influence IMR by using multiple linear regression.

\section{METHODS}

This research is a non-reactive research, in which the subjects studied were not aware if they were participated in the study so there was no reaction by the research subjects. The data used came from secondary data taken from online publications of the East Java Province Central Bureau of Statistics in 2015. The population used was all districts/cities in East Java, with a sample of 38 districts/cities in East Java.

The independent variable $(\mathrm{X})$ used in this study is the percentage of the age of the first woman married under 17-year-old (X1), and the percentage of non-medical delivery assistants (X2), then the dependent variable is the Infant Mortality Rate (Y) in 2015 in East Java. Test analysis for all variables using multiple linear regression analysis tests. The analysis step begins by collecting secondary data that will be used, testing hypotheses, testing linear regression assumptions, then making equation regression models. 


\section{RESULT}

IMR in East Java in 2015 was influenced by several factors which were then analyzed by multiple linear regression tests. Research variables included the age of the first mother married under 17-year-old and the delivery assistance by non-medical personnel in 2015 , which was derived from secondary data taken from East Java Province Central Bureau of Statistics. Before being analyzed using multiple linear regression, each variable must be tested using the classic regression assumptions, which include the normality test, linearity test, heteroscedasticity test, multicollinearity test, and autocorrelation test. If all the variables have met the assumptions, then the variable modelling can be done using multiple linear regression.

\section{IMR in 2015 in East Java}

In 2015, IMR in East Java reached 24.00, which means that there were 24 infant deaths per 1000 live births in that year. In East Java, Probolinggo (district) occupies the highest position for IMR in 2015, which is around 56.24 deaths per 1000 births, and the lowest IMR is in Blitar (city), which is 20.67 deaths per 1000 births

Table. 1 below shows 10 districts/cities in East Java according to the highest IMR calculation, covering Probolinggo (district), Jember (district), Bangkalan (district), Situbondo (district), Bondowoso (district), Pasuruan (district), Sampang (district), Pamekasan (district), and finally Bojonegoro (district).

Table 1. Ten regencies / cities with the highest IMR in East Java in 2015

\begin{tabular}{lc}
\hline \multicolumn{1}{c}{ Regency / City } & IMR 2015 \\
\hline Probolinggo & 56.24 \\
Jember & 50.20 \\
Bangkalan & 48.85 \\
Situbondo & 48.62 \\
Bondowoso & 46.09 \\
Pasuruan & 44,13 \\
Sampang & 43.95 \\
Sumenep & 42.81 \\
Pamekasan & 42.73 \\
Bojonegoro & 34.86 \\
\hline
\end{tabular}

Cases of infant deaths in East Java in 2015 averaged 28.8511. It can be concluded that in
2015, in East Java Province, the incidents of infant deaths reached 29 cases per 1,000 births. With a minimum value of 16.05 and a maximum value of 56.24 .

\section{Concurrent Test (F Test)}

Concurrent tests or simultaneous tests performed on multiple linear regression intending to detect independent variables, namely the age at which mothers first get married and the delivery assistance by nonmedical personnel, have a significant or no effect on the dependent variable, the Infant Mortality Rate.

The $F$ test value on the variable obtained a significance of 0.000 at an alpha confidence level of $5 \%$ so that the conclusions obtained were that the independent variable, namely the age of the mother's first marriage and the delivery assistance by non-medical personnel, had a joint effect on infant mortality.

\section{Partial Test (t-test)}

Partial test or known as the t-statistic test is done to see in the regression model that is formed that each variable $\mathrm{X}$ (independent) influences per variable and significantly to the dependent variable, the Infant Mortality Rate at an alpha confidence level of 5\%.

The t-test value obtained a significance of 0.000 for the variable age of first marriage mothers, and the birth attendance variable by non-medical personnel has a significance value of 0.014 . The conclusion from these results is that the age at which the mother first married and the delivery assisted by non-medical personnel gave a partial effect on Infant Mortality Rate $<0.05$ ).

\section{Regression Assumption Test Results}

\section{Normality test}

The normality test in multiple linear regression is performed on the residual variance. The purpose of the regression normality test is to look at the residual regression model whether it has a normal distribution (Sulistiyono and Sulistyowati, 2017).

The significance value generated using Kolmogorov Smirnof's One Sample is 0.200 which can be interpreted that the data has a normal distribution ( $p$ value> 0.05 ). Therefore, 
the data fulfil the assumption of normality for multiple linear regression.

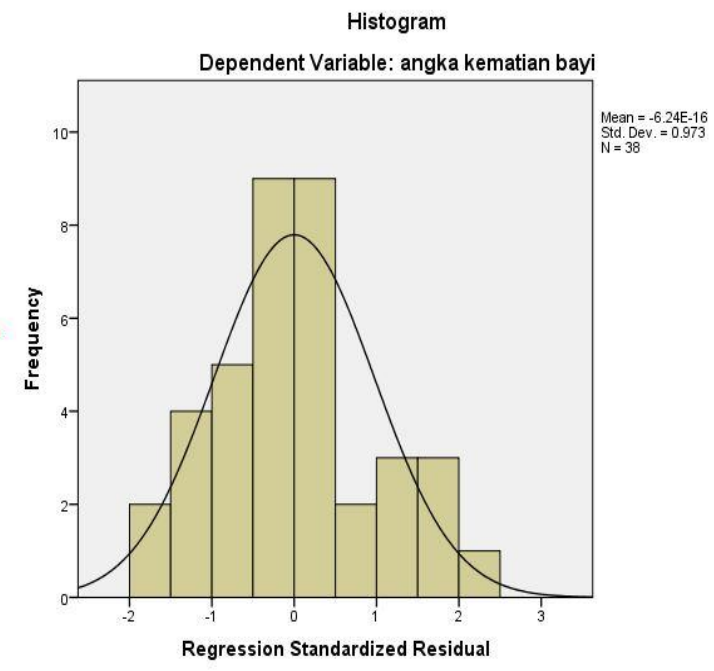

Figure 1. Histogram Test for Residual Normality in Multiple Linear Regression

\section{Linearity Test}

The purpose of doing a linearity regression test is to see whether there is a significant linear correlation between the dependent and independent variables. It is said to have a linear correlation on a variable if the resulting significance is $<0.05$ ( $\mathrm{p}$-value $<0.05$ ).

In the linearity test, the regression assumptions that have been carried out revealed the significance value obtained in the ANOVA table is 0,000 . Therefore, the conclusion that can be drawn is that the variable used has fulfilled the linear regression assumptions. The Normal PP Plots image also shows that the data is in a straight-line pattern.

\section{Heteroskesdatisity Test}

The heteroscedasticity assumption test is a test to find out the variance in the residual variance in all observations in the regression model. Linear regression analysis must fulfil the classic assumption regression test requirements where one of them is the heteroscedasticity test. The assumption of heteroscedasticity is not met if $\mathrm{HO}$ is accepted, so the regression modelling becomes invalid to be used as a modelling tool.

In the heteroscedasticity test using the Spearman Rho test, the significance obtained was greater than alpha (alpha $=0.05)$ for each independent variable, namely for the first age variable for mothers to marry, the significance value was 0.950 and for the delivery assisted by non-medical personnel variable, the significance value was 0.786 . That is, there was no heteroscedasticity on the independent variables used ( $\mathrm{p}$ value> 0.05). Thus, the regression model is said to be valid and can be used.

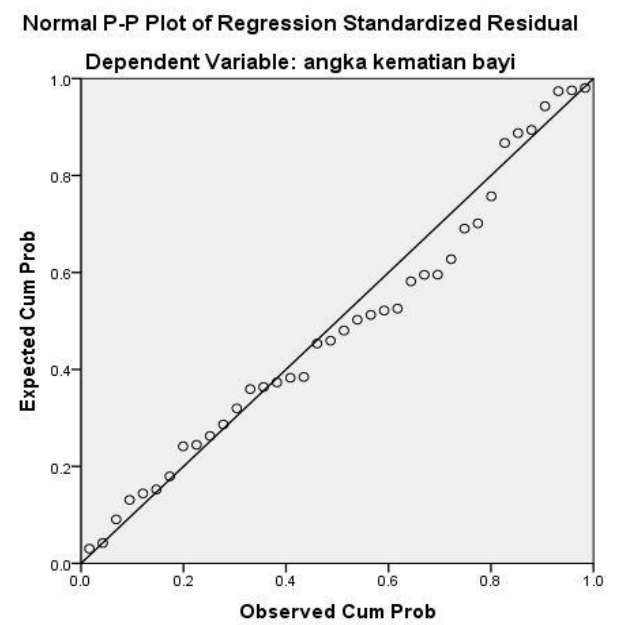

Figure 2. Normal PP plot Test of Linear Assumption of Multiple Linear Regression

\section{Multicollinearity Test}

Multicollinearity assumption test is used to see the correlation or relationship between independent variables in a multiple regression model (Sulistyono and Sulistiyowati, 2017). The basis for decision making in the multicollinearity test is using VIF (Variance Inflation Factor) and based on the Tolerance value. The assumption is that if the VIF number $<10$ and tolerance $>0.10$, it can be mentioned that there is no multicollinearity in the regression model.

In the multicollinearity test using a computer application, it was found that tolerance for the two independent variables was $>0.1$ and VIF $<10$, and the Condition Index was $<30$, so the conclusion obtained was that there was no multicollinearity in the two independent variables used.

Table 2. Assumption Multicollinearity Regression Test

\begin{tabular}{|c|c|c|c|}
\hline \multirow{2}{*}{\multicolumn{2}{|c|}{ Model }} & \multicolumn{2}{|c|}{$\begin{array}{c}\text { Collinearity } \\
\text { Statistics }\end{array}$} \\
\hline & & Tolerance & VIF \\
\hline 1 & $\begin{array}{l}\text { First age married } \\
\text { Nonmedical }\end{array}$ & 0.625 & 1.600 \\
\hline & helper & 0.625 & 1.600 \\
\hline
\end{tabular}




\section{Autocorrelation Test}

The autocorrelation assumption test aims to find out the existence of deviations in the autocorrelation assumption, namely between residuals in each observation whether there is a correlation in the regression model. In order to test the assumption of autocorrelation, an analytical method can be used by applying the Durbin Watson test, assuming that no autocorrelation is formed if the $\mathrm{d}$ value is between $\mathrm{dU}$ and (4-dU).

Through the calculation of the DurbinWatson value produces a value of 2.127 with many observations (n) of 38 and many independent variables of $2(\mathrm{k}=2)$. There is a dU value according to the Durbin Watson table of 1.594 and (4-dU) valued at 2.406, then the Durbin Watson value is between $\mathrm{dU}$ and (4-dU). Then it can be said that the value of Durbin Watson is not autocorrelated or error free.

\section{Equation Regression Model}

Finally, variables that have been tested together, partial test and regression assumption test, it is stated that both simultaneously and partially the two independent variables influence the dependent variable, the Infant Mortality Rate, and the two independent variables meet all the assumptions of multiple linear regression.

Following the results of data processing using a computer application of all variables, it is known that the value of $\mathrm{R}$ is 0.867 , meaning that the level of close relationship formed on the independent variable with the dependent variable is very close. The range of scale $\mathrm{R}$ is between 0 to 1 , assuming the stronger the relationship between variables, the value of $R$ will get closer to 1 , and vice versa if the value of $\mathrm{R}$ is closer to the number 0 , the weaker the relationship will occur.

$\mathrm{R}$ square value on the results of data processing amounted to 0.751 or $75.1 \%$. This means that $75.1 \%$ of IMR in East Java in 2015 was influenced by the age of first marriage and the delivery assistance of non-medical personnel and the remaining $24.9 \%$ was determined because of the influence of other factors not used in the research model as the studied variables. According to the output of data processing results it was found that the two independent variables used were significant at an alpha confidence level of 5\%. The general equation of the multiple linear regression model is:

$$
Y=b_{0}+b X_{1}+b X_{2}
$$

The regression equation models for the dependent and independent variables in the study are as follows:

$$
\begin{aligned}
\operatorname{IMR}(Y) & =16,064+1,319 *(\text { mother's first } \\
& \text { marriage age })+0,439 * \text { (non- } \\
& \text { medical birth attendants }) .
\end{aligned}
$$

The constant value of 16.064 states that if there are no variables for the age of first marriage and the delivery assistance variable by non-medical personnel, the Infant Mortality Rate is declared constant or constant at 16.064.

Coefficient values for the two independent variables, namely the age at which mothers first get married and the delivery assistance by nonmedical personnel, have a positive value indicating the direction of the relationship, i.e. if the rising age of the mother when married for the first time and the delivery assistance by nonmedical personnel, the IMR increases.

\section{DISCUSSION}

Infant deaths in Indonesia can be caused by various factors. The cause of infant death, in general, can be divided into two: direct cause which is the innate condition of the infant from birth and indirect cause that is influenced by external environmental factors. Therefore, the

\begin{tabular}{|c|c|c|c|c|c|c|}
\hline \multirow{2}{*}{\multicolumn{2}{|c|}{ Model }} & \multicolumn{2}{|c|}{$\begin{array}{l}\text { Unstandardized } \\
\text { Coefficient }\end{array}$} & \multirow{2}{*}{$\begin{array}{c}\begin{array}{c}\text { Standardized } \\
\text { Coefficient }\end{array} \\
\text { Beta } \\
\end{array}$} & \multirow[t]{2}{*}{$\mathbf{t}$} & \multirow{2}{*}{ Sign. } \\
\hline & & B & St. Error & & & \\
\hline \multirow[t]{3}{*}{1} & (Constanta) & 16.064 & 1.751 & & 9.177 & 0.000 \\
\hline & $\begin{array}{l}\text { Mother's first married } \\
\text { age }\end{array}$ & 1.319 & 0.210 & 0.670 & 6.279 & 0.000 \\
\hline & Nonmedical helper & 0.463 & 0.179 & 0.276 & 2.589 & 0.014 \\
\hline
\end{tabular}
factors used as variables to be examined this time are the factors that originate from direct

Table 3. Results of Multiple Linear Regression Modelling on IMR in East Java Province 2015 
causes and indirect causes. These variables are the age at which mothers first married and the delivery assistance by non-medical personnel.

Based on multiple linear regression tests, the age at which mothers first get married, and the delivery assistance by non-medical personnel is significant and influential with IMR in East Java in 2015 as the dependant variable.

The age at which a mother first married is one of the important variables, which can play a role as a factor that causes death in both mother and infant. A woman who chooses to get married at a younger age, then the reproductive period that occurs will be longer. The longer the period between fertile age that can allow mothers to become pregnant with infertile age in young mothers, will make it possible for mothers to give birth to more than one child. Conversely, the age of a woman to be able to have a safe pregnancy and childbirth is between the ages of 20-30 years, because the occurrence of pregnancy and childbirth outside the age range of 20-30 years will cause risks that will be dangerous to pregnancy and result in infant death (Indonesian Ministry of Health, 2010). Young marriages can cause problems in women's reproductive health when a woman is pregnant, giving birth, and childbirth. During pregnancy, this can lead to abortion, anaemia, and pregnancy poisoning, because the reproductive organs have not yet matured. Whereas during delivery and childbirth, it will cause premature delivery and postpartum infections will easily occur, and in infants can cause several direct causes of death such as infants with low birth weight (LBW) and congenital abnormalities in infants (Nainggolan, 2014).

Based on the results of the study, the age of first married women had an effect on IMR producing a significant value of 0,000 ( $p$ value> $0.05)$. This is in line with research conducted by Ashani (2012), he explained that there was a large and opposite direction between the age of the mother with the incidence of infant mortality, that is, if the age group of pregnant women was getting higher, the possibility of less infant mortality and vice versa, the lower the maternal age group, the greater the infant mortality. The purpose of the statement is, the younger the mother is during pregnancy, the higher the risk of infant death, and vice versa.

However, these results are inversely proportional to the research conducted by
Kusumawardani and Handayani (2018). In the research, it was stated that between the age of the mother with the incidence of death in infants there was no significant relationship. Although there is no correlation between maternal age and the incidence of death in infants, precaution must be taken if a pregnant woman under 20year-old is a vulnerable age who can be at risk of developing foetus growth during pregnancy. According to Indonesian Ministry of Health (2010) Mothers with pregnancies that occur under the 20-year-old are generally not physically reached in their reproductive organs, as a result of prolonged delivery, or other disorders that may occur due to lack of mental readiness to become new parents. While pregnant women over 35-year-old often experience blood vessel system disorders, which results in the risk of miscarriage will increase.

The degree of health can also be determined by who carries out delivery assistance, especially in indicators related to the welfare of the mother, infant, and general health services. However, the reality, there are still a strong influence of a dukun to do delivery assistance. A dukun is a person who aids in delivery who still do not have the expertise in determining the presence of emergency signs in pregnancy and childbirth women who may be harmful to the mother and infant. That is because they only rely on skills and experience that are hereditary.

Based on the results of data processing, it was found that delivery assistance by nonmedical personnel influenced infant mortality cases in East Java in 2015. The results of the significant value through a partial test (t-test) were 0.014 , so the research hypothesis was accepted, meaning that there was significant influence among the delivery assistance by nonmedical personnel with Infant Mortality Rate as the dependent variable ( $\mathrm{p}$-value $<0.05$ ).

These results are comparable to studies by Kurniawan and Melaniani (2018). Researchers said that the delivery assistance variable shows that if more infants are delivered to be assisted by non-medical personnel, it will increase the chances of infant death. Other studies from Waang (2012) states that a health worker who is not or less competent will make the community reluctant to come to a health facility for delivery which causes the risk of infant death will increase. In line with research by Aulele (2012) which stated that the incidence of infant deaths 
can be influenced by someone who is giving birth assisted by a non-medical personnel. Aulele said that if the non-medical delivery assistance variable increased by one unit, there would also be an increase in the number of infant mortality cases in Maluku in 2010.

The reason given by most mothers to choose their birth assisted by a dukun or paraji is in terms of the interaction between the community and the delivery assistance, which tend to be more comfortable with the dukun than the midwife or doctor because they already know and are familiar with the dukun who will help the mothers. The environment where the mother lives and economic level also make the community closer to the dukun than the health worker. According them, the delivery assisted by dukun will cost less compared to the delivery assisted by health workers. Furthermore, the dukun or paraji is also willing to care for the mother and infant for several days after the mother gives birth, giving postpartum massage to the mother.

The delivery assisted by non-medical personnel can cause many problems for both mother and infant. Therefore, we need training or coaching by health workers to the dukun on the help of mothers giving birth in a sterile and safe manner, because all officers who have to assist the delivery must know and have abilities related to pregnancy properly first (Purwanti, 2010).

The training conducted to the dukun is called the midwife partnership with the dukun, which is a model of collaboration between midwife and dukun to promote maternal and infant safety. The duty of the dukun at the time of delivery is to deliver the mother to the midwife, the dukun is also obliged to remind the family to prepare everything related to childbirth and its completeness, and assist the midwife in caring for the mother and baby during childbirth, or can provide motivation to the mother and family if needed to do a referral action (Salham et al., 2008).

Indirectly, the factors that influence the IMR decline will be biased to affect the Life Expectancy (LE) of the community in the region, which is a benchmark in measuring the quality of the population and is a consideration for the socioeconomic success of the population. The statement is the same as the results of research by Danasari and Wibowo (2017), that there is an opposite direction relationship between IMR (Infant Mortality
Rate) and LER (Life Expectancy Rate), that is if IMR increases, LER will decrease further, and vice versa.

The decrease in IMR is a clear manifestation of the increase in the delivery assisted by health workers. Access to easily accessible health facilities as well as increasing procedures for caring for infants properly is also an important factor to be able to reduce the infant deaths, especially in East Java (Zuhairoh and Melaniani, 2018).

\section{CONCLUSIONS AND SUGGESTIONS}

\section{Conclusion}

From the analysis of research using secondary data from East Java Province Central Bureau of Statistics in 2015, it can be concluded that the IMR in East Java in 2015 reached 24.00 with average infant mortality of 28,511 , which means that the number of cases of infants who died in East Java in 2015 reached 29 cases of deaths per 1000 births, with the highest fatality case in Probolinggo which was 57 cases, and the lowest death case was in Blitar by 17 cases.

Predictor variables or independent variables that influence simultaneously or partially on Infant Mortality Rate are all independent variables namely the variable age when the mother was first married (X1) and the delivery assisted by non-medical personnel (X2).

Before doing the modelling, all variables are tested by multiple linear regression assumptions and all variables meet all regression assumptions.

From the results of data processing, the linear regression models obtained are:

$$
\begin{aligned}
\operatorname{IMR}(Y)= & 16,064+1,319 * \text { (mother's first } \\
& \text { marriage age }+0,439 * \text { (non- } \\
& \text { medical birth attendants }) .
\end{aligned}
$$

\section{Suggestion}

It is recommended that several strategies for reducing infant mortality be implemented by the East Java Provincial Government, so that it can provide an impetus for improving the health status of the people, especially. Decreasing cases of infant deaths can be done by limiting the age of marriage to women, increasing adolescent knowledge about reproductive health, increasing the number of competent health workers in community health service 
centers and equitable distribution of supporting health facilities in each region, especially in health facilities located far away in some areas so that it is more easily accessed by the community.

\section{REFERENCES}

Ashani, T.A., 2012. Kematian Bayi Menurut Karakteristik Demografi dan Sosial Ekonomi Rumah Tangga di Provinsi Jawa Barat (Analisis Data Kor SDKI 2007). Jurnal Bumi Indonesia, 1 (3), pp.326-335.

Aulele, S.N., 2012. Pemodelan Jumlah Kematian Bayi di Provinsi Maluku Tahun 2010 dengan Menggunakan Regresi Poisson. Jurnal Barekeng, 5 (2), pp.23-27.

East Java Province Central Bureau of Statistics, 2019. Angka Kematian Bayi (AKB) Penduduk Jawa Timur Menurut Kabupaten/Kota, 2012-2016. [online] East Java Province Central Bureau of Statistics. Available at: <https://jatim.bps.go.id/statictable/2017/0 6/07/389/angka-kematian-bayi-akbpenduduk-jawa-timur-menurut-kab-ban20-20-2016. html>.

Danasari, L. S., and Wibowo, A., 2017. Angka Harapan Hidup di Jawa Timur Tahun 2015. Jurnal Biometrika dan Kependudukan, 6 (1), pp.17-25.

Indonesian Ministry of Health, 2010. Profil Kesehatan Indonesia Tahun 2010. Jakarta.

Kurniawan, R., and Melaniani, S., 2018. Hubungan Paritas, Penolong Persalinan dan Jarak Kehamilan dengan Angka Kematian Bayi di Jawa Timur. Jurnal Biometrika dan Kependudukan, 7 (2), pp.113-121.

Kusumawardani, A., and Handayani, S., 2018. Karakteristik Ibu dan Faktor Risiko Kejadian Kematian Bayi di Kabupaten Banjarnegara. Jurnal Promosi Kesehatan Indonesia, 13 (2), pp.168-178.

Mosley, W.H., and Chen, L.C., 1984. An Analytical Framework for the Study of Child Survival in Developing Countries. Population and Development Review, 10 (Supplement), pp. 25-45.

Nainggolan, T.F., 2014. Dampak Pernikahan
Dini pada Remaja Putri di Desa Mangkai Baru Lecamatam Lima Puluh Kabupaten Batubara Tahun 2014 (Studi Kualitatif). Thesis. Universitas Sumatera Utara.

Purwanti, D.D., 2010. Faktor yang Mempengaruhi Angka Kematian Bayi di Provinsi Jawa Timur Tahun 2008. Thesis. Universitas Airlangga.

Rachmah, N.F., and Purhadi, 2014. Pemodelan Jumlah Kematian Ibu dan Jumlah Kematian Bayi di Provinsi Jawa Timur Menggunakan Bivariate Poisson Regression. Jurnal Sains dan Seni Pomits, 3 (2), pp.194-199.

Salham, M. M., Baan, F., Arianto, Mansyur, N., and Pageno, I., 2008. Kemitraan Bidan dengan Dukun Bayi dalam Rangka Alih Peran Pertolongan Persalinan di Sulawesi Tengah. Palu.

Sitorus, R., 2009. Makanan Sehat dan Bergizi. Bandung: Yrama Widy.

Sulistyono, and Sulistiyowati, W., 2017. Peramalan Produksi dengan Metode Regresi Linier Berganda. PROZIMA (Productivity, Optimization, and Manufacturing System Engineering), 1 (2), pp.82-89.

Sulistyowati, A., 2009. Buku Asuhan Kebidanan pada Ibu Nifas. Yogyakarta: CV Andi Offset.

Syaifuddin, 2011. Pelayanan Kesehatan Maternal Neonatal. Jakarta: Bina Pustaka Foundation.

Waang, I.H., 2012. Analisis Upaya Penurunan Kematian Ibu dan Bayi melalui Pelaksanaan Revolusi Kartu Ibu dan Anak di Kabupaten Alor Provinsi Nusa Tenggara Timur. Thesis. Universitas Indonesia.

Wibisono, Y., 2005. Metode Statistik. Yogyakarta: Gajah Mada University Press.

Winarno, D., 2009. Analisis Angka Kematian Bayi di Jawa Timur dengan Pendekatan Model Regresi Spasial. Thesis. Institut Teknologi Sepuluh November.

Zuhairoh, Z. A., and Melaniani, S., 2018. Pengaruh Angka Kematian Bayi, Angka Partisipasi Murni, Rasio Ketergantungan Terhadap Indeks Pembangunan Manusia Provinsi Jawa Timur. Jurnal Biometrika dan Kependudukan, 7 (1), pp.87-95. 